University of Nebraska - Lincoln

DigitalCommons@University of Nebraska - Lincoln

6-13-2004

\title{
Optimization of cell density and dilution rate in Pichia pastoris continuous fermentations for production of recombinant proteins
}

Mehmet Inan

Michael M. Meagher

Wenhui Zhang

Chih Ping Liu

Follow this and additional works at: https://digitalcommons.unl.edu/chemeng_biomolecular

Part of the Biochemical and Biomolecular Engineering Commons

Inan, Mehmet; Meagher, Michael M.; Zhang, Wenhui; and Ping Liu, Chih, "Optimization of cell density and dilution rate in Pichia pastoris continuous fermentations for production of recombinant proteins" (2004). Papers in Biomolecular Engineering. 3.

https://digitalcommons.unl.edu/chemeng_biomolecular/3

This Article is brought to you for free and open access by the Chemical and Biomolecular Engineering Research and Publications at DigitalCommons@University of Nebraska - Lincoln. It has been accepted for inclusion in Papers in Biomolecular Engineering by an authorized administrator of DigitalCommons@University of Nebraska - Lincoln. 


\section{Wenhui Zhang · Chih-Ping Liu · Mehmet Inan \\ Michael M. Meagher \\ Optimization of cell density and dilution rate in Pichia pastoris continuous fermentations for production of recombinant proteins}

Received: 23 September 2003/ Accepted: 13 June 2004/Published online: 15 July 2004

(c) Society for Industrial Microbiology 2004

\begin{abstract}
This paper provides an approach for optimizing the cell density $\left(X_{\mathrm{c}}\right)$ and dilution rate $(D)$ in a chemostat for a Pichia pastoris continuous fermentation for the extracellular production of a recombinant protein, interferon $\tau(\mathrm{INF}-\tau)$. The objective was to maximize the volumetric productivity $\left(Q, \operatorname{mg} I N F-\tau 1^{-1} \mathrm{~h}^{-1}\right)$, which was accomplished using response surface methodology (RSM) to model the response of $Q$ as a function of $X_{\mathrm{c}}$ and $D$ within the ranges $150 \leq X_{\mathrm{c}} \leq 450 \mathrm{~g}$ cells (wet weight $)^{-1}$ and $0.1 \mu_{\mathrm{m}} \leq D \leq 0.9 \mu_{\mathrm{m}}\left(\mu_{\mathrm{m}}=0.0678 \mathrm{~h}^{-1}\right.$, the maximum specific growth rate obtained from a fed-batch phase controlled with a methanol sensor). The methanol and medium feed rates that resulted in the desired $X_{\mathrm{c}}$ and $D$ were determined based on the mass balance. From the RSM model, the optimal $X_{\mathrm{c}}$ and $D$ were $328.9 \mathrm{~g} \mathrm{l}^{-1}$ and $0.0333 \mathrm{~h}^{-1}$ for a maximum $Q$ of $2.73 \mathrm{mg} \mathrm{l}^{-1} \mathrm{~h}^{-1}$. The model of specific production rate $\left(\rho, \operatorname{mg~INF-~} \tau \mathrm{g}^{-1}\right.$ cells $\left.\mathrm{h}^{-1}\right)$ was also established and showed the optimal $X_{\mathrm{c}}=287.7 \mathrm{~g} \mathrm{l}^{-1}$ and $D=0.0361 \mathrm{~h}^{-1}$ for the maximum $\rho$ (predicted to be $\left.8.92 \times 10^{-3} \mathrm{mg}^{-1} \mathrm{~g}^{-1} \mathrm{~h}^{-1}\right)$. The methanol specific consumption rate $\left(v, \mathrm{~g}\right.$ methanol $\mathrm{g}^{-1}$ cells $\left.\mathrm{h}^{-1}\right)$ was calculated and shown to be independent of the cell density. The relationship between $v$ and $\mu$ (specific growth rate) was the same as that discovered from fed-batch fermentations of the same strain. The approach developed in this study is expected to be applicable to the optimi-
\end{abstract}

\footnotetext{
W. Zhang $\cdot$ M. Inan $\cdot$ M. M. Meagher $(\bowtie)$

Biological Process Development Facility,

Department of Chemical Engineering,

University of Nebraska-Lincoln,

207 Othmer Hall, Lincoln, NE 68588-0643, USA

E-mail:mmeagher1@unl.edu

Tel.: + 1-402-4722342

Fax: + 1-402-4726989

C.-P. Liu

Pepgen Corporation, Alameda,

CA 94502, USA

Present address: W. Zhang

XOMA Ltd., Berkeley,

CA 94710, USA
}

zation of continuous fermentations by other microorganisms.

Keywords Pichia pastoris - Continuous fermentation · Optimization $\cdot$ Model Interferon $\tau$.

Response surface methodology

\section{Introduction}

Known as an efficient host for the production of recombinant proteins, Pichia pastoris is widely used. While most of the literature describes $P$. pastoris fermentations using a fed-batch mode, several successful continuous fermentations have also been reported. Digan et al. [3] described a continuous fermentation with a $P$. pastoris methanol utilization-plus phenotype $\left(\mathrm{Mut}^{+}\right)$for the extracellular production of bovine lysozyme c2. A cell density of $120 \mathrm{~g}^{-1}$ dry cell weight (DCW) was achieved at a dilution rate of $0.05 \mathrm{~h}^{-1}$. Bovine lysozyme c2 concentration and cell density in the chemostat were approximately $350 \mathrm{mgl}^{-1}$ and $100 \mathrm{~g} \mathrm{l}^{-1} \mathrm{DCW}$, respectively. Goodrick et al. [4] reported a continuous fermentation constitutively expressing human chitinase under the control of the pGAP promoter. A feed medium containing $30 \%$ glucose (the limiting carbon source) was fed in the continuous phase. A cell density of $400 \mathrm{~g} \mathrm{l}^{-1}$ wet cell weight (WCW) and a rh-chitinase concentration of $360 \mathrm{mg}^{-1}$ were maintained in the chemostat at a dilution rate of $0.83 \mathrm{day}^{-1}\left(0.0346 \mathrm{~h}^{-1}\right)$ that continued for 30 days. Curvers et al. [2] ran a $P$. pastoris $\mathrm{Mut}^{+}$continuous fermentation that expressed human chymotrypsinogen B by feeding a medium containing $197.5 \mathrm{~g} \mathrm{l}^{-1}$ methanol ( $25 \%$ by vol.). The feed rate was controlled by maintaining the methanol concentration at a constant level of $4 \mathrm{~g} \mathrm{l}^{-1}$ and resulted in a cell density of $65 \mathrm{~g} \mathrm{l}^{-1} \mathrm{DCW}$ and volumetric productivity of $25 \mathrm{mg} \mathrm{l}^{-1} \mathrm{~h}^{-1}$.

The advantage of the $P$. pastoris expression system is its high cell density (up to $130 \mathrm{~g}^{-1} \mathrm{DCW}$ ) on a simple 
defined basal salts medium and the ability to produce grams per liter quantities of recombinant proteins. However, proteases can accumulate and have an adverse impact on protein production and quality. Thus, it is necessary to optimize the cell density and dilution rate in a continuous fermentation. Such an investigation with $P$. pastoris has not been reported to date. The objective of this paper was to model the response of productivity to various cell densities and dilution rates, using an experimental design based on the response surface methodology (RSM). A Mut ${ }^{+} P$. pastoris that extracellularly expresses the recombinant ovine interferon- $\tau$ $(\mathrm{IFN}-\tau)$ was used in this study. This strain has been successfully used to produce IFN- $\tau$ in fed-batch fermentations [8]. IFN- $\tau$ consists of 172 amino acids (about $20 \mathrm{kDa}$ ) and has a wide range of antiviral, antiproliferative and immunomodulatory activities; and it might be used as a therapeutic agent for treating human diseases like viral infections and autoimmune disorders $[1,6]$.

\section{Materials and methods}

Strain and shake-flask culture

A X-33 P. pastoris strain, which has the $\mathrm{Mut}^{+}$phenotype and extracellularly expresses the recombinant ovine protein IFN- $\tau$, was obtained from Pepgen Corp. (Alameda, Calif., USA). It has been described elsewhere [5]. Frozen stock $(1 \mathrm{ml})$ was used to inoculate a 1-1 Erlenmyer flask containing $200 \mathrm{ml}$ of buffered minimal glycerol yeast extract medium, containing $1 \%$ yeast extract (with amino acids but without ammonium sulfate), $2 \%$ peptone, $1.34 \%$ yeast nitrogen base, $4 \times 10^{-5} \%$ biotin, $1 \%$ glycerol, $100 \mathrm{mM}$ potassium phosphate, $\mathrm{pH}$ 6.0). The flask was incubated for $20-24 \mathrm{~h}$ at $30^{\circ} \mathrm{C}$ and $300 \mathrm{rpm}$ (shake rate) and reached an optical density at $600 \mathrm{~nm}$ of $10-20$.

\section{Batch and fed-batch phase on glycerol}

The entire $200 \mathrm{ml}$ of propagated shake-flask culture was used to inoculate a 5-1 fermentor (Bioflo 3000; New Brunswick Scientific Co., Edison, N.J., USA) containing 3-41 of basal salts medium that contains (per liter):

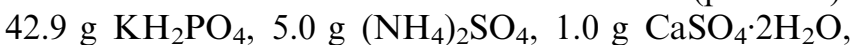
$11.7 \mathrm{~g} \mathrm{MgSO}_{4} \cdot 7 \mathrm{H}_{2} \mathrm{O}, 14.3 \mathrm{~g} \mathrm{~K}_{2} \mathrm{SO}_{4}, 1.92 \mathrm{~g}$ citric acid, $40.0 \mathrm{~g}$ glycerol and $2.0 \mathrm{ml}$ PTM4 trace salts solution (filter-sterilized, added separately). The PTM4 solution contains (per liter): $2.0 \mathrm{~g} \mathrm{CuSO}_{4} \cdot 5 \mathrm{H}_{2} \mathrm{O}, 7.0 \mathrm{~g} \mathrm{ZnCl}_{2}$, $0.08 \mathrm{~g} \mathrm{NaI}, 22.0 \mathrm{~g} \mathrm{FeSO}_{4} \cdot 7 \mathrm{H}_{2} \mathrm{O}, 3.0 \mathrm{~g} \mathrm{MnSO}_{4} \cdot \mathrm{H}_{2} \mathrm{O}$, $0.2 \mathrm{~g}$ Biotin, $0.2 \mathrm{~g} \mathrm{Na}_{2} \mathrm{MoO}_{4} \cdot 2 \mathrm{H}_{2} \mathrm{O}, 0.02 \mathrm{~g}$ boric acid, $0.5 \mathrm{~g} \mathrm{CoCl}_{2}$ and $2.0 \mathrm{ml} \mathrm{H}_{2} \mathrm{SO}_{4}$. The $\mathrm{pH}$ was maintained at 5.0 using undiluted (about 28\%) ammonium hydroxide, the dissolved oxygen (DO) was maintained above $20 \%$ saturation by adjusting the agitation rate and using a pure oxygen supply (oxygen sparging was initiated at maximum agitation speed) and the temper- ature was maintained at $30^{\circ} \mathrm{C}$. The cells grew to approximately $100 \mathrm{~g}^{-1}$ WCW during the glycerol batch-phase and the cell density was increased to the desired level (150-450 $\left.\mathrm{g} \mathrm{l}^{-1} \mathrm{WCW}\right)$ using a $63 \%(\mathrm{w} / \mathrm{v})$ glycerol solution containing $0.2 \%$ (v/v) PTM4 that was fed at $20 \mathrm{~g} \mathrm{l}^{-1} \mathrm{~h}^{-1}$. During the glycerol fed-batch phase, growth was limited by the glycerol feed rate and no glycerol accumulation occurred.

\section{Continuous phase on methanol}

To adaptively switch the substrate from glycerol to methanol, $2 \mathrm{ml} \mathrm{l}^{-1}$ methanol was injected into the fermentor, and simultaneously, the glycerol feed rate was programmed to decrease linearly from $20 \mathrm{~g} \mathrm{l}^{-1} \mathrm{~h}^{-1}$ to zero over a period of $3 \mathrm{~h}$. This 3 -h period is considered a transition phase that is important for cells to adapt the methanol efficiently and completely [9]. After the transition phase, the continuous phase was initiated by feeding $100 \%$ methanol containing $0.1-0.2 \%(\mathrm{w} / \mathrm{v})$ antifoam (KFO 673; KABO Chemicals, Wyo., USA) and basal salts medium (without glycerol, $\mathrm{pH}$ adjusted to 6.0). The broth $\mathrm{pH}$ was adjusted to and maintained at 6.0 , while temperature and DO were still kept at $30^{\circ} \mathrm{C}$ and $>20 \%$, respectively. During the continuous phase, growth was limited by methanol. Figure 1 shows the schematic diagram of the continuous fermentation system. The substrate feed rates followed the experimental design.

\section{Analysis}

Time-course samples were centrifuged at $2,000 \mathrm{~g}$ for 10 min to determine the cell density ( $\mathrm{g} \mathrm{WCW} 1^{-1}$ broth)

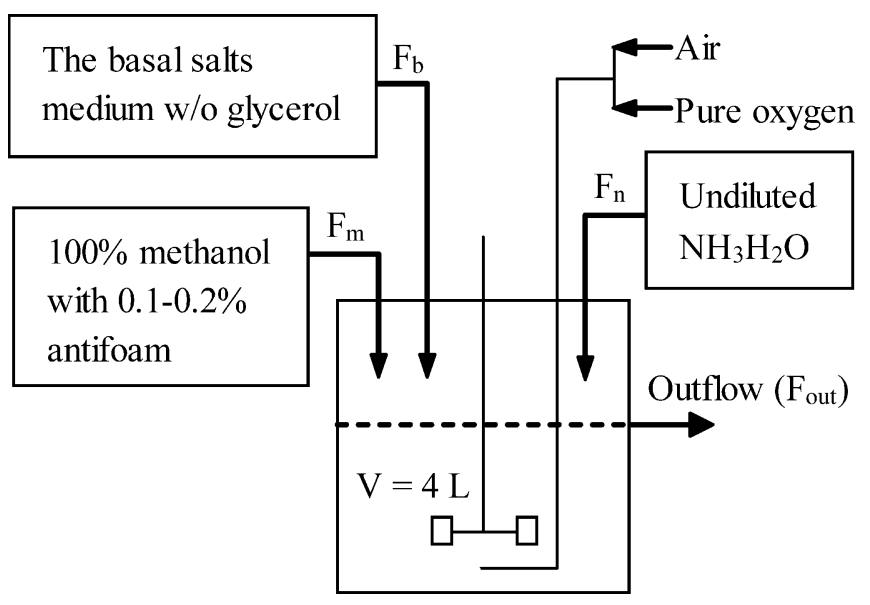

Fig. 1 Schematic diagram of the continuous fermentation. The feed rates of methanol $\left(F_{\mathrm{m}}\right)$ and basal salts medium without glycerol $\left(F_{\mathrm{b}}\right)$ were set based on the experimental design to result in the desired cell density and dilution rate in the chemostat; and the feed rate of ammonium hydroxide $\left(F_{\mathrm{n}}\right)$ was automatically controlled to maintain the $\mathrm{pH}$ at 6.0. Total inflow rate $F_{\text {in }}=F_{\mathrm{b}}+F_{\mathrm{m}}+F_{\mathrm{n}}$. In chemostat, $F_{\text {out }}=F_{\text {in }}$; and the volume $(V)$ was maintained at 41 constantly by pumping the outflow through an outlet set at the same level 
and measure the IFN- $\tau$ concentration in the supernatant with the method described elsewhere [8].

\section{Experimental design}

Mass balance

The $\mathrm{pH}$ of the basal salts medium feed solution (without glycerol) was adjusted to 6.0 with concentrated ammonium hydroxide; and thus the amount of ammonium hydroxide consumed $\left(F_{\mathrm{n}}\right)$ during chemostat is very small compared with $F_{\mathrm{b}}$ and $F_{\mathrm{m}}$. The total flow into the bioreactor $\left(F_{\text {in }}, 1 \mathrm{~h}^{-1}\right)$ and the dilution rate $\left(D, \mathrm{~h}^{-1}\right)$ can be approximated as:

$F_{\text {in }}=F_{\mathrm{b}}+F_{\mathrm{m}}$

$D=F_{\text {in }} / V=\mu$

where $\mu$ is the specific growth rate and $V=41$. In our previous work [9], we established a growth model for $P$. pastoris describing the relationship between the methanol concentration $S\left(\mathrm{~g} \mathrm{l}^{-1}\right)$ and $\mu\left(\mathrm{h}^{-1}\right)$ :

$\mu=\frac{0.146 S}{1.5+S+S^{2} / 8.86}$

Here, we use this model to estimate the methanol concentration in the chemostat $\left(\mathrm{S}_{\mathrm{c}}\right)$ for a given dilution rate $(D)$. Equation 3 shows that as $S$ increases so does $\mu$, up to a methanol concentration of $3.65 \mathrm{~g} \mathrm{l}^{-1}$, at which point substrate inhibition occurs, resulting in a decrease in $\mu$. In this study, we do not exceed $3.65 \mathrm{~g} \mathrm{l}^{-1}$. Using the curve-fitting software Table Curve 2D (SPSS, Chicago, Ill., USA) we can solve Eq. 3 for $S_{\mathrm{c}}$ as a function of $D$ :

$S_{\mathrm{c}}=\frac{0.071+6.1 D-85.7 D^{2}}{1-21.8 D+117.1 D^{2}}$

According to the mass balance, the cell density in the chemostat $\left(X_{\mathrm{c}}\right)$ is:

$X_{\mathrm{c}}=Y_{X / S}\left(S_{\mathrm{in}}-S_{\mathrm{c}}\right)$

$S_{\text {in }}=790 F_{\mathrm{m}} / F_{\text {in }}$

where $S_{\text {in }}\left(\mathrm{g}^{-1}\right)$ is the methanol concentration in the feed, $790 \mathrm{~g} \mathrm{l}^{-1}$ is the methanol density, $Y_{X / S}$ is the apparent cell yield on methanol ( $\mathrm{g} \mathrm{WCW} \mathrm{g}^{-1}$ methanol) and varies with $\mu$ [9]. $Y_{X / S}$ can be estimated based on the maximum growth rate $\left(\mu_{\mathrm{m}}=0.0678 \mathrm{~h}^{-1}\right)$ and the maximum methanol specific consumption rate $\left(v_{\mathrm{m}}=0.0564 \mathrm{~g}\right.$ methanol $\left.\mathrm{g}^{-1} \mathrm{WCW} \mathrm{h}^{-1}\right)$ determined previously for $P$. pastoris expressing IFN- $\tau$ [8]:

$Y_{X / S}=\mu_{\mathrm{m}} / \nu_{\mathrm{m}}=1.2 \mathrm{~g} \mathrm{WCW} / \mathrm{g}$ methanol

The production of IFN- $\tau$ under continuous culture was optimized using a central composite design [7] based on the variables $X_{\mathrm{c}}$ and $D$. Using Eqs. 1, 2, 3, 4, 5, 6 and 7, it was possible to determine the feed rates $F_{\mathrm{m}}$ and $F_{\mathrm{b}}$ that would result in the desired $X_{\mathrm{c}}$ and $D$. Because
$Y_{X / S}$ is determined based on $\mu_{\mathrm{m}}$ and $v_{\mathrm{m}}$, the feed rates were an approximation of the desired feed rate for the desired $X_{\mathrm{c}}$ and $D$, but this is sufficient for the central composite design.

\section{Results}

The range of $X_{\mathrm{c}}$ was set at 150-450 and the range of $D$ at $0.1 \mu_{\mathrm{m}} \leq D \leq 0.9 \mu_{\mathrm{m}}$ with $\alpha=1.41421$ (the distance from the center of the design space to a star or axial point) and the center points $=2$. Table 1 shows the ten different $X_{\mathrm{c}}$ and $D$, based on the design and the actual $X_{\mathrm{c}}$ and $D$. The difference between the design and actual $X_{\mathrm{c}}$ is caused by using a $Y_{X / S}$ estimated from the $\mu_{\mathrm{m}}$ and $v_{\mathrm{m}}$ (Eq. 7) used to calculate the $F_{\mathrm{m}}$ and $F_{\mathrm{b}}$ for all the runs. The deviation of $D$ is caused by foam production and an instability in the aeration rate that caused the broth volume to vary. The INF- $\tau$ concentration $\left(P_{\mathrm{c}}, \mathrm{mg}^{-1}\right)$ was determined for each condition and used to calculate the volumetric productivity $Q\left(\mathrm{mg}^{-1} \mathrm{~h}^{-1}\right)$ and specific production rate $\rho\left(\mathrm{mg} \mathrm{g}^{-1} \mathrm{WCW} \mathrm{h}^{-1}\right)$, based on the actual $X_{\mathrm{c}}$ and $D$ :

$Q=D P_{\mathrm{c}}$

$\rho=D P_{\mathrm{c}} / X_{\mathrm{c}}$

A quadratic model was used to regress $Q$ and $\rho(P<0.05$ for both) as a function of $X_{\mathrm{c}}$ and $D$; and the results of the analysis of variance (ANOVA) are presented in Tables 2 and 3 [7]:

$$
\begin{aligned}
Q= & -9.85+0.0576 X_{\mathrm{c}}+186.44 D-8.14 \times 10^{-5} X_{\mathrm{c}}^{2} \\
& -2191.83 D^{2}-0.123 X_{\mathrm{c}} D \\
\rho= & -0.0294+1.726 \times 10^{-4} X_{\mathrm{c}}+0.746 D-2.51 \\
& \times 10^{-7} X_{\mathrm{c}}^{2}-7.205 D^{2}-7.857 \times 10^{-4} X_{\mathrm{c}} D
\end{aligned}
$$

Figures 2 and 3 show the response surface plots of $Q$ and $\rho$ based on Eqs. 10 and 11, respectively. From these

Table 1 Central composite design for the two variables $X_{\mathrm{c}}$ and $D$,

\begin{tabular}{|c|c|c|c|c|c|c|c|}
\hline \multicolumn{3}{|l|}{ Design } & \multicolumn{2}{|c|}{ Feed rate } & \multicolumn{3}{|c|}{ Result } \\
\hline $\begin{array}{l}\text { Run number } \\
\text { (randomized) }\end{array}$ & $X_{\mathrm{c}}$ & $D$ & $F_{\mathrm{m}}$ & $F_{\mathrm{b}}$ & $X_{\mathrm{c}}$ & $D$ & $P_{\mathrm{c}}$ \\
\hline 1 & 300 & 0.0068 & & 0.019 & 243.7 & 0.0076 & 45.4 \\
\hline 2 & 406 & 0.05 & 0.091 & 0.121 & 323.2 & 0.0355 & 85.2 \\
\hline 3 & 300 & 0.0339 & 0.043 & 0.093 & 232.7 & 0.0420 & 49.8 \\
\hline 4 & 450 & 0.0339 & 0.064 & 0.071 & 415.5 & 0.0268 & 75.0 \\
\hline 5 & 300 & 0.0339 & 0.043 & 0.093 & 285.7 & 0.0310 & 68.5 \\
\hline 6 & 300 & 0.0610 & 0.078 & 0.166 & 363.3 & 0.0500 & 39.0 \\
\hline 7 & 150 & 0.0339 & 0.022 & 0.114 & 201.3 & 0.0344 & 47.0 \\
\hline 8 & 194 & 0.0531 & 0.044 & 0.169 & 216.2 & 0.0427 & 32.0 \\
\hline 9 & 406 & 0.0147 & 0.025 & 0.034 & 329.1 & 0.0136 & 148.5 \\
\hline 10 & 194 & 0.0147 & 0.012 & 0.047 & 203.0 & 0.0170 & 37.0 \\
\hline
\end{tabular}
the feed rates derived from Eqs. 1, 2, 3, 4, 5, 6, 7, the actual $X_{\mathrm{c}}$ and $D$ obtained and the ITF- $\tau$ concentration $\left(P_{\mathrm{c}}, \mathrm{mg} \mathrm{l}^{-1}\right)$ achieved in the chemostat 
Table 2 ANOVA for significance of regression of $Q$ with Eq. 10 [9]

\begin{tabular}{llllll}
\hline $\begin{array}{l}\text { Source of } \\
\text { variation }\end{array}$ & $\begin{array}{l}\text { Sum of } \\
\text { squares }\end{array}$ & $\begin{array}{l}\text { Degrees of } \\
\text { freedom }\end{array}$ & $\begin{array}{l}\text { Mean } \\
\text { square }\end{array}$ & $F_{0}$ & $P$ value \\
\hline Regression & 4.981 & 5 & 0.996 & 8.8 & 0.0279 \\
Error & 0.453 & 4 & 0.113 & & \\
Total & 5.434 & 9 & & & \\
\hline
\end{tabular}

Table 3 ANOVA for significance of regression of $\rho$ with Eq. 11 [9]

\begin{tabular}{llllll}
\hline $\begin{array}{l}\text { Source of } \\
\text { variation }\end{array}$ & $\begin{array}{l}\text { Sum of } \\
\text { squares }\end{array}$ & $\begin{array}{l}\text { Degrees of } \\
\text { freedom }\end{array}$ & $\begin{array}{l}\text { Mean } \\
\text { square }\end{array}$ & $F_{0}$ & $P$ value \\
\hline Regression & $5.09 \times 10^{-5}$ & 5 & $1.02 \times 10^{-5}$ & 6.3 & 0.0497 \\
Error & $6.49 \times 10^{-6}$ & 4 & $1.62 \times 10^{-6}$ & & \\
Total & $5.74 \times 10^{-5}$ & 9 & & & \\
\hline
\end{tabular}

models, we obtain both the optimal $X_{\mathrm{c}}=328.9 \mathrm{~g} \mathrm{l}^{-1}$ and $D=0.0333 \mathrm{~h}^{-1}$ for the maximum $Q$ (predicted to be $2.73 \mathrm{mg} \mathrm{l}^{-1} \mathrm{~h}^{-1}$ ) and the optimal $X_{\mathrm{c}}=287.7 \mathrm{~g} \mathrm{l}^{-1}$ and $D=0.0361 \mathrm{~h}^{-1}$ for the maximum $\rho$ (predicted to be $8.92 \times 10^{-3} \mathrm{mg} \mathrm{g}^{-1} \mathrm{~h}^{-1}$ ).

The specific methanol consumption rate $v$ (g methanol $\mathrm{g}^{-1} \mathrm{WCW}^{-1}$ ) is:

$v=\left(S_{\text {in }}-S_{\mathrm{c}}\right) D / X_{\mathrm{c}}$

With the results of $X_{\mathrm{c}}$ and $D$ in Table 1 , we calculated $v$ and investigated different models of $v$ as a function of $X_{\mathrm{c}}$ and $D$. The ANOVA showed that $X_{\mathrm{c}}$ is not a significant model term (data not shown). The regression obtained from various trials is a linear model:

$v=0.754 D+0.003$

This equation describes the relationship between $v$ and $\mu$ (at chemostat $D=\mu$ ) and is about the same as what Sinha et al. [8] discovered from the fed-batch fermentations of the same strain $(v=0.75 \mu+0.0055)$.

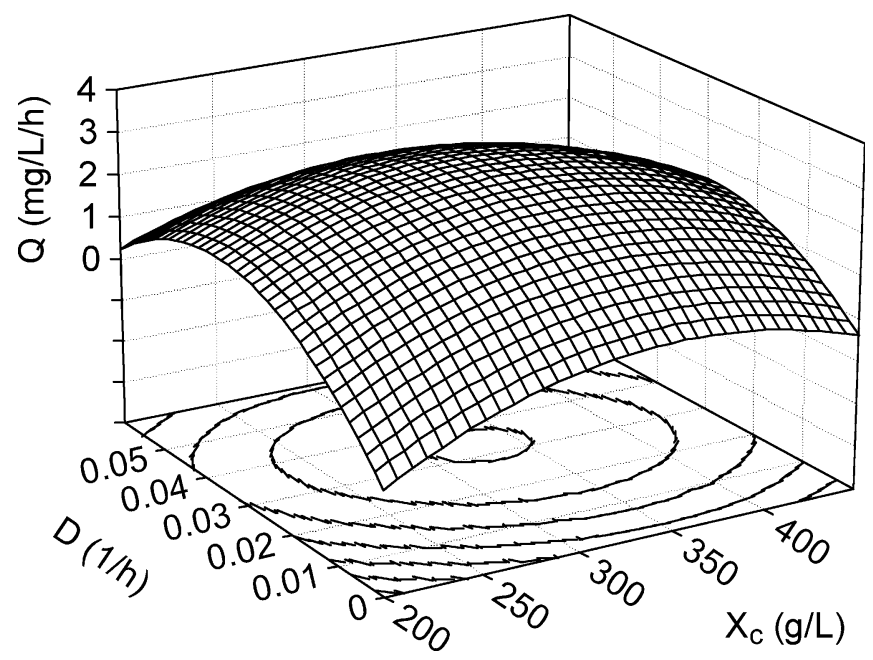

Fig. 2 Response surface of volumetric productivity $(Q)$ to the dilution rate $(D)$ and cell density $\left(X_{\mathrm{c}}\right)$ at the chemostat based on Eq. 10

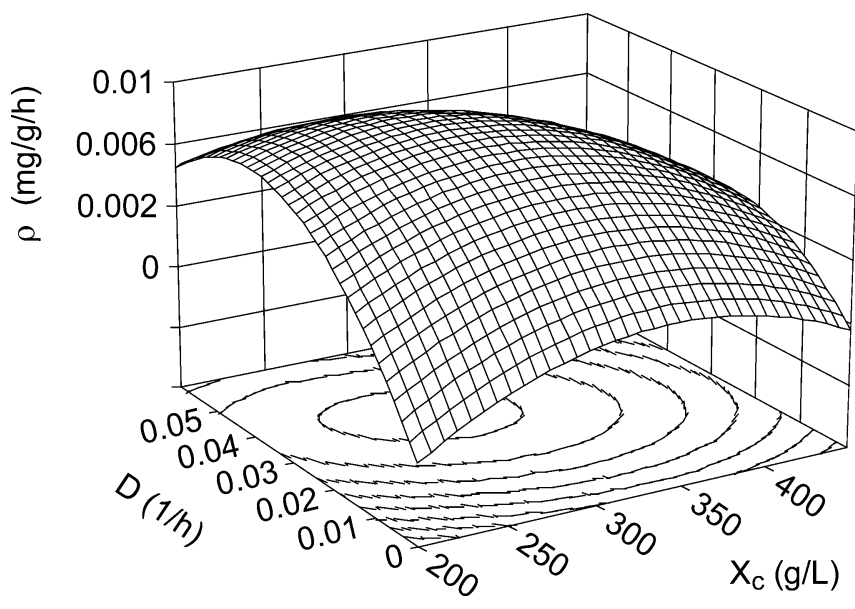

Fig. 3 Response surface of specific production rate $(\rho)$ to the dilution rate $(D)$ and cell density $\left(X_{\mathrm{c}}\right)$ at the chemostat based on Eq. 11

\section{Discussion}

The objective of process optimization for a continuous fermentation is to maximize volumetric productivity $(Q)$, which for this study was dependent on cell density $\left(X_{\mathrm{c}}\right)$ and dilution rate $(D)$. RSM [7] provides a solution to the experimental design with these two factors varied over multi-levels. However, $X_{\mathrm{c}}$ is a dependent on the feeding strategy, rather than an independent variable (such as temperature) that can be simply set to a desired value. Thus, the challenge is how to determine the feed rate of the limiting substrate (methanol) to obtain the desired $X_{\mathrm{c}}$ in the experimental design. Based on the mass balance, we solved this problem through the estimation of $S_{\mathrm{c}}$ with the growth model (Eq. 3) developed previously [9]. Within the ranges $0.1 \mu_{\mathrm{m}} \leq D \leq 0.9 \mu_{\mathrm{m}}$ and $150 \leq$ $X_{\mathrm{c}} \leq 450$, we found that the $S_{\mathrm{c}}$ calculated from Eq. 4 was much less than the $S_{\text {in }}$ determined from the mass balance. Thus, $S_{\mathrm{c}}$ in Eqs. 5 and 12 can be approximated to zero, which simplifies the mass balance calculation, eliminating the need for a growth model.

The relationship between $\mu$ and $v$ from Eq. 13 is about the same as that obtained from fed-batch fermentations of the same strain [8] and also quite similar to other P. pastoris strains [9-11]. Based on these results, we can express the relationship as $v=\mathrm{a} \mu+\mathrm{m}$, with $\mathrm{a}=0.73-0.84$ and $\mathrm{m}=0.003-0.013$. Taking average values for a and $\mathrm{m}, Y_{X / S}$ can be estimated as $Y_{X / S \text {-AvG }}=\mu /$ $(0.785 \mu+0.008)$, which takes into account the maintenance coefficient $(\mathrm{m})$ and is closer to the actual $Y_{X / S}$ than that estimated by Eq. 7. The deviation of the actual $X_{\mathrm{c}}$ from the desired $X_{\mathrm{c}}$ can also be reduced using $Y_{X / S \text {-AvG }}$ for calculating the feed rates, $F_{\mathrm{m}}$ and $F_{\mathrm{b}}$. For this study, the factors affecting the deviation of the actual $D$ from the desired $D$ are the inflow rates, agitation speed, aeration rate (gas hold-up) and foaming. The first two factors are easy to maintain constant, while latter two need closer monitoring and control. A proper amount of 
antifoam is required in the feed solutions to inhibit foam production during the whole continuous phase.

Although the actual $X_{\mathrm{c}}$ and $D$ obtained from the runs did not exactly match the design due to the reasons discussed above, the models of $Q$ and $\rho$ corresponding to $X_{\mathrm{c}}$ and $D$ were successfully established (Eqs. 10, 11) through the ANOVA significance test of the regressions [7]. From the models, we found the optimal $X_{\mathrm{c}}$ (328.9 $\mathrm{g} \mathrm{l}^{-1}$ ) for the maximum $Q$ was higher than the optimal $X_{\mathrm{c}}\left(287.7 \mathrm{~g}^{-1}\right)$ for the maximum $\rho$, while the optimal $D\left(0.0333 \mathrm{~h}^{-1}\right)$ for the maximum $Q$ was about the same as the optimal $D\left(0.0361 \mathrm{~h}^{-1}\right)$ for the maximum $\rho$. This indicates that, in a continuous fermentation, the optimal conditions for maximizing $\rho$ may not necessarily be the optimal conditions for maximizing $Q$. We also noticed that the optimal $\mu(=D)$ for the maximum $\rho$ obtained was different from that $\left(0.025 \mathrm{~h}^{-1}\right)$ obtained from the fed-batch fermentations [8]. This is because the fed-batch phase, with a constant $\mu$, is a quasi-steady state (cell density is not constant) and the optimal $\mu$ obtained corresponds to a range of cell densities (200$\left.415 \mathrm{~g} \mathrm{l}^{-1}\right)$. The optimal $\mu$ obtained from the chemostat corresponds to the optimal cell density $\left(287.7 \mathrm{~g}^{-1}\right)$. For methanol consumption capability, the result showed $v$ was independent of cell density within the range 200 $415 \mathrm{~g}^{-1}$. This discovery supports that a constant $\mu$ can be realized in a fed-batch phase by simply carrying out the feeding strategy that is based on the model $v=\mathrm{a} \mu+\mathrm{m}$, as observed previously [9-11]. The approach developed in this study is expected to be applicable to the optimization of continuous fermentations by other microorganisms.

Acknowledgements We thank Carlee Rastede, Priya Nataraj and Mike Dux (undergraduate students at Department of Chemical Engineering, University of Nebraska-Lincoln; UNL) for running the fermentations; and we thank Sheila Bart and other staff in the QC Division of the Biological Process Development Facility at
UNL for the IFN- $\tau$ assay. Pepgen Co. (Alameda, Calif., USA) provided the $P$. pastoris strain.

\section{References}

1. Alexenko AP, Leaman DW, Li J, Roberts RM (1997) The antiproliferative and antiviral activities of IFN- $\tau$ variants in human cells. J Interferon Cytokine Res 17:769-779

2. Curvers S, Brixius P, Klauser T, Thoemmes J, Weuster-Botz D, Takors R, Wandrey C (2001) Human chymotrypsinogen B production with Pichia pastoris by integrated development of fermentation and downstream processing. Part 1. Fermentation. Biotechnol Prog 17:495-502

3. Digan ME, Lair SV, Brierley RA, Siegel RS, Williams ME, Ellis SB, Kellaris PA, Provow SA, Craig WS, Velicelebi G, Harpold MM, Thill GP (1989) Continuous production of a novel lysozyme via secretion from the yeast, Pichia pastoris. Biotechnology 7:160-164

4. Goodrick JC, Xu M, Finnegan R, Schilling BM, Schiavi S, Hoppe H, Wan NC (2001) High-level expression and stabilization of recombinant human chitinase produced in a continuous constitutive Pichia pastoris expression system. Biotechnol Bioeng 74:492-497

5. Johnson TM, Holaday SK, Sun Y, Subramaniam PS, Johnson HM, Krishna NR (1999) Expression, purification, and characterization of interferon- $\tau$ produced in Pichia pastoris grown in a minimal medium. J Interferon Cytokine Res 19:631-636

6. Sinha J, Plantz BA, Zhang W, Gouthro M, Schlegel VL, Liu CP, Meagher MM (2003) Improved production of IFN- $\tau$ by $\mathrm{Mut}^{+}$strain of Pichia pastoris using an optimized methanol feed profile. Biotechnol Prog 19:794-802

9. Zhang W, Bevins MA, Plantz BA, Smith LA, Meagher MM (2000) Modeling Pichia pastoris growth on methanol and optimizing the production of a recombinant protein, the heavychain fragment $\mathrm{C}$ of botulinum neurotoxin, serotype A. Biotechnol Bioeng 70:1-8

10. Zhang W, Potter KJ, Plantz BA, Schlegel VL, Smith LA, Meagher MM (2003) Pichia pastoris fermentation with mixedfeeds of glycerol and methanol: growth kinetics and production improvement. J Ind Microbiol Biotechnol 30:210-215

11. Zhang W, Smith LA, Meagher MM (2004) Maximizing secreted production of recombinant proteins in Pichia pastoris fed-batch fermentation. Biotechnol Prog (submitted) 